\title{
REPRODUCTION OF REAL ESTATE VALUATION METHODOLOGY IN PRACTICE. AN ATTEMPT AT IDENTIFYING SOURCES OF DIVERGENCES
}

\author{
Ewa Kucharska-Stasiak, prof. \\ Department of Economics of Industry and Capital Markets \\ Faculty of Economics and Sociology \\ University of Lodz \\ e-mail: ewkuchar@interia.pl
}

\begin{abstract}
The objective of the study is to try and identify the reasons for the detachment of the valuation practice from its methodology. Two methods have been used in the paper: the analysis method and the case study method, under which fourteen property valuation reports posted on websites and two opinions about the property valuation prepared for court purposes in order to detect and identify sources of deviations from the valuation methodology have been analyzed. The study, besides theoretical aspects, includes references to practical application: pointing out directions of changes in legal regulations and national valuation principles, which should help achieve uniformity in interpreting the valuation concept, allowing the reduction of its uncertainty, understood as the uncertainty of a single valuation and uncertainty as the difference between valuations.
\end{abstract}

Key words: valuation methodology, valuation uncertainty, valuation standards, methodological errors, professional organisation.

\section{JEL Classification: R30.}

Citation: Kucharska-Stasiak E., 2014, Reproduction of the real estate valuation methodology in practice. Attempt at identifying sources of divergences, Real Estate Management and Valuation, vol. 22, no. 2, s. 6779.

DOI: $10.2478 /$ remav-2014-0018

\section{Introduction}

According to the Polish language dictionary edited by Witold Doroszewski "methodology is a set of rules, ways and methods of performing certain work, dealing with an issue," (Słownik języka polskiego (Polish language dictionary) 2000). A similar definition appears in another dictionary: methodology is "... a set of rules concerning methods of performing certain work or a procedure leading to a specific goal," (Słownik języka polskiego 1999).

Valuation methodology, i.e. a set of property valuation rules, has developed over centuries, reproducing the changing concepts of economic value and principles of its measurement, and is influenced by legal regulations, cultural conditions and customs, different in individual countries, as well as factors resulting from the different level of development characterizing real estate markets. However, the need to define market value and valuation practice in the form of national standards did not appear until the 1970s.

In countries with strong institutional solutions, such as the United Kingdom or the United States, the general fundamentals of valuation methodology are included in professional standards published by professional organizations. The first standards were published in the United Kingdom in 1976. Their development and publication was forced by banking and parabank institutions, through critical comments concerning the quality of valuations published in the press, as well as the comments of 
many other market participants (MACKMIN 1999, p.353). In the United Kingdom where several professional organizations operate, all members must observe the standards which have been developed and published by the leading organization - The Royal Institution of Chartered Surveyors (RICS). The situation in the USA is similar. Despite the fact that many professional organizations of valuers operate there, the Uniform Standards of Professional Appraisal Practice (USPAP) published by the Appraisal Foundation must be observed by all members of all professional organizations. The source of in-depth knowledge about the valuation methodology are methodology manuals and textbooks, often written by academicians and practitioners of valuation, approved by professional circles as expressed in the fact that they are published by national organizations ${ }^{1}$.

In countries with poor institutional solutions, such as Germany or Poland, methodology is regulated by law, which by its very nature is incapable of infiltrating the complex matter of valuation. It formulates general rules, recorded in a simplified manner, which should be made more detailed by professional standards, and first and foremost - by valuation manuals. They must follow provisions which, due to the inertia of legal acts and the professional circles' aversion or maybe fear of changing them, do not reflect the contemporary concept of valuation. An example is the legal definition of market value (Article 151.1 of the Real Estate Management Act of 21 August 1997) which, despite the fact that it deviates from the definition provided in the International and European Valuation Standards, has not been adjusted for sixteen years. Additionally, the influence of various schools of valuation is a serious problem at the level of valuation practice, which makes the interpretation of valuation concepts even less uniform. Diverse interpretations of these concepts are presented in literature, as well as at training sessions organized for property valuers.

\section{Motivation for undertaking the dissertation}

Polish practice indicates that property valuers, obliged by the legislator to observe legal regulations and professional standards, often quite freely interpret the valuation methodology generally formulated in law and standards, and in interpretation notes:

- do legal regulations as well as professional standards, through the brevity of content or lack of precision in wording, fail to offer any freedom of interpretation, or is it the property valuers who make mistakes, failing to observe regulations in force,

- is the failure to observe legal regulations - so willingly cited by valuation practitioners - the consequence of misunderstanding them, or refusing to observe them,

- should the aim be to make the legal provisions concerning property valuation more detailed, or on the contrary, following the example of the leading creators of world valuation schools, move the efforts of making the valuation methodology and principles of good practice more precise to the level of standards, methodology textbooks, as well as book publications, the contents of which should be agreed on with leading representatives of the professional circles.

The questions posed seem to be extremely topical under Polish conditions, where the weakness of the professional organization was demonstrated in the undertaking of a resolution about the suspension of professional standards - constituting a threat to all of the professional circles. The supporters of this concept are celebrating their victory; the muzzle has been removed, and what is not written in the law is permitted. The truth is different. There is no profession without standards. The property valuation process is very complex, and the circles of practitioners, deprived of standards, remain defenseless against the recipients of valuations.

\section{Purpose of the study and research method}

The high prestige of the property valuer profession, which required a lot of effort on the part of the professional organization (Polish Federation of Valuers' Associations), has been systematically diminishing over its 20-year period of existence. The effects of these people's work in the form of property valuation reports are generally criticized by the recipients of valuations. The criticism comes both from the banking sector and from local councils, as well as from private recipients who, being more and more aware of the principles of valuation, notice that these principles are not being observed.

\footnotetext{
${ }^{1}$ An example of such a publication is a manual entitled: The Appraisal of Real Estate, published by The Appraisal Institute of Canada. A real estate appraisal handbook has been prepared to accompany it - The Student Handbook to the Appraisal of Real Estate.
} 
The purpose of the study is to attempt to identify the reasons for the valuation practice having become detached from its methodology. Two methods will be applied in the paper: the method of analyzing legal acts, national valuation principles, and literature on the subject, and the case study method under which fourteen property valuation reports published on websites and two opinions on the valuation survey report will be analyzed in order to detect and identify the sources of deviations from the valuation methodology. The study, besides theoretical threads, includes application references: points to the directions of changes in legal regulations and national valuation principles, which should help achieve uniformity of interpretation of the valuation concept, allowing the reduction of its uncertainty, as well as strengthening the significantly weakened authority of a property valuer.

\section{Attempt at exemplification of the disparity between the property valuation methodology and practice}

\subsection{Basis of the analysis}

Two sources of information constituted the basis of the analysis:

- property valuation reports published on websites,

- two opinions presented in court, prepared by property valuers, concerning the valuation of a multifunction property.

Fourteen property valuation reports concerning the valuation of developed land property have been analyzed for the purposes of this survey. They were published on a website as it was needed or required to publicly present their content. None of the property valuation reports were published on a website due to the reprehensibility of their execution. The valuations were carried out during the 2010-2012 period. Valuations for the purpose of providing security for debt claims were most prevalent (57\% of the valuation reports). Three valuation reports, i.e., around $21 \%$, were drawn up for the purposes of bailiffs' proceedings, $21 \%$ for the purpose of sale, and 1 valuation report for financial reporting purposes. In 13 valuation reports, commercial real estate constituted the subject of valuation, whereas one valuation report concerned a property with a housing function and commercial premises. The valuation process was dominated by a comparative approach $-71.4 \%(10$ property valuation reports); an income-based approach was applied sporadically (in 3 valuation reports, which constituted $21.4 \%$ ) and a mixed approach was used in one valuation report (7.2\% of the valuation reports analyzed).

As far as the purpose of the study is concerned, the subject of investigation was the attempt to answer the following questions:

- was the interpretation of market value, defined as the most probable price of the property, i.e. typical, most frequently occurring price in the valuation practice, appropriate. In order to answer this question, the process of achieving the typical market prices by the valuer should be examined, and it should be assessed whether the justifiability of maintaining the existing development was taken into account in the process of estimating market value, whether the valuer undertook deliberations about the most advantageous method of use, and whether or not the existing method of development indicated the need for such searches. The assessment of the so-called internal balance, i.e. the balance between the value of the land and the value of the development, constitutes an important indication to help obtain an answer to the second question. The assessment of "internal balance" was performed for those property valuation reports in which the value of the land and the value of the building were presented separately,

- was the analysis of the real estate market conducted correctly, did it provide the basis for determining market transaction prices in the investment market and in the rental market, did it provide the correct basis for calculating rates of return,

- was the selection of the approach, method, and technique correct, was it correctly justified, and was the procedure of the approach adopted in the property valuation correct,

- was an analysis of the result conducted.

The second source of information were two opinions prepared for the court, concerning the correctness of drawing up the multifunction property valuation report. The authors of these opinions are practicing property valuers, representatives of academic circles. The analysis of those opinions provides a good preview for the evaluation of the understanding of principles of applying the incomebased approach. 


\subsection{Evaluation of materials analyzed}

Results of the analysis of property valuation reports have been collated in Appendix No. 1. The analysis of the material showed that:

1) Market value is not understood correctly:

- although all authors of the property valuation reports cited the statutory definition of this value, not all looked for typical transaction prices in the investment market or in the rental market, because they did not clean the market information by removing the extreme values (in as many as $57 \%$ property valuation reports). Thus, they ignored the legislator's requirement that the conditions under which the transaction was concluded must be known. The rejection of extreme values enables one to assume, with high probability, that other transactions fulfilled market conditions: the parties were independent, they did not act under compulsion, had a definite intention to enter into the transaction, and there was a correct period of display and price negotiations,

- market value is often interpreted as the market average. Market value is not an average, because the distribution of prices is not symmetrical, it is negatively or positively skewed,

- market value was estimated for the actual method of use. The description of the property allows an assumption that, in 3 property valuation reports, the actual method of use corresponded to the most advantageous way. Only in the case of one property valuation report did its author cite the term "most advantageous method of use," negating the justifiability of searching for it (property valuation report No. 14).

- in one of the property valuation reports the market value was confused with the individual value - data on rent rates and operating expenses from the client were adopted in the valuation.

2) In the analyzed valuations, valuers avoided the use of an income-based approach. Out of 14 property valuation reports, only 3, i.e. $21.4 \%$, used such approach. The commercial nature of property, lack of similarity of the property valued to the property disposed of, and low quantity of information from the market about the transactions concluded, formed the basis for the application of the income-based approach in all property valuation reports, all the more so as the authors of the property valuation reports revealed that the investment market did not provide information about transactions concluded for similar properties. Using the comparative approach, they extended the time scale of the analysis to 3 or more years, as well as extending the area covered by the analysis. Thus, they acted contrary to the provision of Interpretation Note No. 1, "Application of comparative approach in property valuation," which states that similar property which had been the subject of sale during the period immediately preceding the valuation date should be used for comparisons (p.3.3. of the Note), as well as contrary to the provision demanding that the analogy to local markets which are similar by type and area be taken into account when assessing the impact of market features on the differentiation of transaction prices - depending on the condition of the market (p.3.11 of the Note). When extending the analysis in spatial terms, valuers should compare the economic potential of areas, which was missing from the property valuation reports. The application of the income-based approach would be more appropriate as it allowed the determination of value in so-called "real time," i.e. as at the valuation date. This is because it is easier to obtain data from the market which allows the determination of market rent prices for similar property than transaction prices from the investment market. A lack of understanding for the valuation methodology was demonstrated in the phrase used by the valuer justifying the rejection of the income-based approach: "there is little probability that the entire space will be rented," (property valuation report No. 8).

3) The valuation methodology is not applied correctly. Errors have been made both in the area of the comparative approach and the income-based one. In the comparative approach:

- dissimilar properties are accepted for comparison, e.g. differing in size or form of holding. These features have not been accepted as attributes which would constitute the basis for assessing corrections,

- valuers apply the average price adjustment method too frequently. They calculate the delta from the entire market, without the rejection of extreme prices. The estimated value does not constitute the market value but the average value. They do not state the features of all properties adopted for this analysis, only the prices of those achieving extreme prices.

In the income-based approach: 
- there is no differentiation between the capitalization rate and the discount rate. The discount rate has been confused with the capitalization coefficient.

4) The lack of result analysis in property valuation reports is a wide-spread occurrence (in over $71 \%$ of property valuation reports).

The Authors, who are at the same time property valuers and representatives of academic circles, charge the second document, i.e. opinions about the property valuation report prepared for court purposes, among other things with:

- not accounting - on the part of income and in the level of rates of return - for the positive changes taking place in the economy during the period of receiving income at a variable level,

- the lack of extrapolation of the previous trends after the forecast period, i.e. at the stage of determining the capitalization rate and the discount rate for the residual value. They suggest that, as at the valuation date (2003), there were solid basis for believing that the capitalization rate which was determined for each city at $12 \%$ would drop to $7-8 \%$ in a few years' time. Errors were revealed in their reasoning pattern, indicating a lack of understanding of the market value category and the methodology for its determination, and namely:

- the market is determined as at a given date. It reflects the condition of the market on that particular day, and the investors' expectations concerning the future on the given day. The condition of the market is reflected in the income generated by the property; the investors' expectations are reflected in the risk of achieving the income, assessed as at the valuation date. The statements on risk do not constitute a simulation of the future. This is a consequence of the interpretation of this value in the light of the National Standard "Market value and Replacement Value," which is consistent with International and European Valuation Standards:

- "the estimated amount stated in the property valuation report reflects the condition of the market and constraints existing on the valuation date, and not on an earlier or later date," ( $p$. 3.2.2. of the standard),

- "the parties act with insight and prudently (....). Prudence is assessed allowing for the condition of the market on the valuation date, without taking into account the information acquired later," (p.3.2.6. of the standard).

The valuation process does not constitute the prediction of the future but reflects the condition of the market on the valuation date. The variable income stream results from the forecasted changes taking place in the market during the period for which the opinion on value has been prepared.

\section{Reasons behind the disparity between the interpretations of the valuation methodology}

We are putting forward a thesis that the reason for the divergences are the methodological errors made in the valuation process. These errors result from the lack of compliance with the valuation rules. The detection of such errors and finding out their sources enables one to protect themselves from making them, which may contribute to the reduction of valuation risk and to improving the reputation of property valuers. Methodical errors may have objective and subjective sources. Although these may be classified separately, they show mutual connections.

\subsection{Objective sources of errors}

Objective sources come from outside the community of valuers (valuation practitioners) and may be the consequence not only of the imprecise method of presenting the valuation methodology in legal regulations and professional standards, but also the imprecise or incorrect presentation of this methodology in literature on the subject or in the teaching process.

Among objective sources originating on the outside, provisions which regulate and explain the valuation methodology in the area of law play an important role. The legal basis of valuation has been regulated in the Real Estate Management Act of 21 August 1997 (consolidated text: Journal of Laws No. 102/2010, item 651) and the Regulation of the Council of Ministers of 14 July 2011, amending the Regulation on real estate valuation and drawing up the property valuation report (Journal of Laws of 11 August 2011). The legislator devoted an entire section (IV) to the valuation of real estate. This section provides more accurate definitions of value, such as: market value (Article 151.1 of the Act), replacement value (Article 151.2), cadastral value (Article 151.3). Valuation approaches were also classified, identifying the comparative approach, income-based approach, cost-based approach, and mixed approach. 
Despite repeated changes in the statutory provisions, many phrases are still ambiguous and some continue to be misleading, constituting the source of free interpretations of the valuation process, and the result of the valuations - cf. Table 1. Critical comments concerning these provisions refer among other things to the method of expressing value: the legislator uses the phrase - as a result of the valuation, market value is determined, replacement value is determined (Article 151.1 of the Act). The term "determine" means "list the characteristic features of something: denote, specify, define: Determine the time when the work of art was created. Determine someone's age. Determine the color of a dress," (Słownik języka polskiego (Polish language dictionary) 1999). The term "determine" therefore suggests precision of the result. Unfortunately, activities undertaken in the valuation process, such as analytical, interpretational and even calculating activities, do not allow the precise determination of input data, as they always contain subjective elements, and constitute the source of valuation uncertainty understood as the uncertainty of a single valuation and as a difference between valuations ${ }^{2}$. It has been accepted that uncertainty in valuations is a real and universal occurrence (FRENCH, GABRIELLI, 2003).

The uncertainty of a single valuation refers to the uncertainty of the input data, whereas uncertainty between valuations refers to output data. The former, resulting from the uncertainty of input data adopted for the valuation, is considered as:

1) typical uncertainty for a valuation process. Different sources of typical uncertainty of valuation are indicated, such as:

- the availability of market data for similar real estate,

- the assessment of current and future market conditions,

- the adoption of specific data concerning the valuation of the property in question, such as: the level of the capitalization rate, the level of market rent, market expectations of rent increase, and the share of vacant properties.

Each entry of input data is accompanied by a certain degree of uncertainty.

2) untypical uncertainty, resulting from the condition of the market or unique features of the property. Quick changes in the market as well as special prices of property, e.g. a swimming pool in a detached house, extremely large cubic capacity, or multifunctionality, increase the uncertainty of data adopted for valuation. The adoption of data for valuation on the basis of market information does not constitute a mathematic exercise but a heuristic approach, i.e. the skill to detect new facts and correlations between market facts (FRENCH, GABRIELLI, 2003).

The level of uncertainty depends on the degree of market development in a given country, which consists of: the legal system (set of property law acts, spatial planning), the transparency of the market (lack of or difficult access to data), the level of education of property valuers, but also strong fluctuations in real estate markets, and the pressure exerted by clients on the valuation market.

Regardless of the level of development, in the real estate market the client pays for a subjective interpretation of an objective scientific analysis and calculation (GILBERTSON 2001). The more individualized the features of a property, as a physical as well as legal entity, the less active and transparent the market, and the less mature - the more difficult, the objectivization process. Valuation reflects the quality of information and the method of its processing. This means that the less mature the market, the higher the uncertainty of the valuation of a single property, and the higher the differences between two valuations of the same property may be. This means that in emerging markets, the scale of uncertainty seems to be higher.

To sum up, as the value - the result of valuation - is burdened with uncertainty, a term such as "determining" the value is misleading to the recipients of the valuation, suggesting that they are receiving a certain result. The correct word which the legislator should use to reflect the complexity of the valuation process is the "estimation" of the market value, estimation of the replacement value. In the Polish language dictionary, the term "estimate" refers to value: "estimate - determine the material value of something (feature, size, quantity, etc.): assess someone's value, appearance, conduct, etc.; evaluate, appraise: Estimate someone's assets at one million zloty," (Słownik języka polskiego (Polish language dictionary) (1999). Estimation contains an element of uncertainty.

The legislator defined the market value of property imprecisely, not in compliance with the concept of value as an economic category, and not in compliance with the concept of value stated in

\footnotetext{
${ }^{2}$ More: E. Kucharska-Stasiak, Niepewność wyceny jako przedmiot badań (Uncertainty of valuation as the subject of research)
} 
the International and European Valuation Standards: in Article 151.1, the legislator states precisely that it is "...its most probable price which may be obtained in the market, determined allowing for transaction prices, with the adoption of the following assumptions:

1) the parties to the agreement were independent of each other, did not act under compulsion and had a definite intention to enter into the agreement,

2) the time necessary to display the property in the market and to negotiate the terms of the agreement had lapsed."

The definition provided above refers to valuation methodology (allowing for transaction prices) which is not methodologically correct; the definition does not contain the phrase "on the valuation date," which is a necessary element when defining a category which changes over time. It also uses the past tense when indicating the conditions which should be met in transactions from which data are taken for valuation, instead of referring to the conditions of a future transaction for which the value is determined. Though they may seem irrelevant to some, these deviations from the market value definition, which has been adopted and accepted all over the world, are not without relevance to the process of valuation and the interpretation of its result. The absence of the phrase "on the valuation date" creates a temptation to adopt not only data on prices originating from notarial deeds, but also data on rents from a distant past. In the property valuation reports analyzed, data from three, four years prior to the valuation date were used. These prices reflect different market conditions, and different investors' expectations. In accordance with Article 153.1, they are adjusted according to the time lapsed. Time, however, is not a parameter which constitutes the source of these changes. It is a parameter in which these expectations are revealed. The legislator does not specify the method used to adjust prices registered in the market. The extrapolation of the price trend - a method generally used in Poland - is an extremely unreliable method. This was confirmed by the period of a strong boom in the real estate market in the years 2006-2008, and the downturn which followed it.

The use of the past tense in the definition of market value (the parties were independent, they did not act under compulsion, they had a definite intention to enter into the transaction) makes it so the value of the property cannot constitute the most probable price which can be obtained in a transaction. In order for this price to be the most probable one, market conditions for conducting a valuation ought to be fulfilled in the very transaction for which it is drawn up. The more the conditions differ from market conditions, the bigger the difference between the price and value.

A simplified provision, which may be misleading to the valuer and the recipient of the valuations, is the provision of Article 152.3 of the Act: "The market value of property is determined using the comparative approach or the income-based approach. If the existing constraints do not permit the use of the comparative approach or the income-based approach, the market value of property is determined using the mixed approach. The cost-based approach is used to determine the replacement value of property." The wording of this Article may suggest that each application of the comparative and the income-based approach may lead to the determination of market value, and each application of the cost-based approach - to the determination of replacement value. This is possibly how the statutory provision was understood by the author of property valuation report No. 13, who tried to estimate the value of property by taking data on rent rates and operating expenditures from the property in question. The type of value as the result of valuation is not determined by the approach applied, but by the data taken for the valuation. Approaches constitute only tools in the valuation process. If the valuer takes the typical, i.e. most frequently occurring prices (from the investment market or from the rental market), and if the typical risk of generating income, the typical level of vacant properties, and the typical expenditure required for replacement are reproduced when using these tools, the outcome will be the market value or the replacement value. If the data adopted come from outside the range of typical, most frequently occurring market parameters, individual value, not market value, is obtained as a result of the valuation. Also the subsequent Article 153.1-153.3 of the Act, in which the legislator defines individual approaches, lacks a precise definition of when their application allows for values which objectivize the market to be reached.

Table 1

Real Estate Management Act as the source of potential divergences in the valuation process

Item Existing provision Suggested provision


as a result of the valuation, market value is

1 determined, replacement value is determined (Article 151.1 of the Act).

The market value of a property is its most probable price which may be obtained in the market, determined allowing for transaction prices, with the adoption of the following assumptions:

2 1) the parties to the agreement were independent of each other, did not act under compulsion and had a definite intention to enter into the agreement:

2) the time necessary to display the property in the market and to negotiate the terms of the agreement had lapsed

"The market value of property is determined using the comparative approach or the income-based approach. If the existing constraints do not permit the use of the comparative approach or the income-based approach, the market value

3 of property is determined using the mixed approach. The cost-based approach is used to determine the replacement value of the property." as a result of the valuation, market value is estimated, replacement value is estimated (Article 151.1 of the Act)

The market value of a property is its most probable price which may be obtained in the market on the valuation date, determined allowing for transaction prices, with the adoption of the following assumptions:

1) the parties to the agreement were independent of each other, did not act under compulsion and had a definite intention to enter into the agreement:

2) the time necessary to display the property in the market and to negotiate the terms of the agreement had lapsed

"The market value of property and values other than the market value are determined using the comparative approach or the income-based approach. The estimation of market value requires the adoption of typical transaction prices, reflecting typical vacant properties and typical risk of generating income. If the existing constraints do not permit the use of the comparative approach or the income-based approach, the market value of property is determined using the mixed approach. The costbased approach is used to determine the replacement value of the property."

Source: Own study.

The provisions in the Regulation of the Council of Ministers of 21 September 2004 constitute a detailed specification of the valuation methodology. The Regulation determines, among other things the types of methods and techniques of valuation, as well as methods of determining the value of property using individual approaches, methods and techniques. The provisions of the Regulation do not explain the doubts which arise from the Act. They create new ones. An example of these doubts is the provision concerning the income-based approach; in the discounted future income technique, the legislator uses the term "forecast period," which may suggest that the valuation is to reflect the changes taking place in the market environment, changes in supply and demand during this period arising from the changes in the business cycle, or changes in the real estate market cycle (par.10.2). The term "forecast" is also used by Interpretation Note No. 2 "Use of the income-based approach in property valuation." It is clear that the term "forecast" was misinterpreted by the authors of the cited opinions prepared for the court.

Unfortunately, authors of textbooks do not undertake to dispel the doubts concerning valuation methodology. Literature on the subject is mainly directed at presenting procedures in property valuation, making the legislator's provisions the only reference point, without explaining the valuation concept set on the grounds of economy. Polish literature lacks a textbook to match "The Appraisal of Real Estate," a textbook translated into Polish, written by a select team from professional circles, and approved and published by a professional organization.

The teaching process, in which the diversified interpretation of statutory provisions is revealed, also becomes an objective source of divergences between the provisions of methodology and valuation practice. Additionally, the influence of different schools of valuation constitutes a significant problem at the stage of teaching valuation methodology, which increases the lack of uniformity of interpretation with regard to valuation concepts. For example, in the interpretation of the incomebased approach, the influence of the American school appears at the teaching stage - and in that school, the market is never stable. In accordance with the American valuation concept, after a tenancy 
agreement concluded for a definite period has expired, not the valuation date rent but the rent reflecting the extrapolation of previous market trends is taken for the valuation. The adoption of such interpretation is incompliant with the concept of the British valuation school, on which the assumptions of the income-based approach are based in Poland, and in which, after the expiry of the tenancy agreement, the rent from the valuation date is taken. The adoption of the American valuation concept is incompliant with the legislator's regulation which stipulates that the number of years of the forecast period depends on the expected period during which the income from the valued property will change (par. 10.2 of the Regulation). This means that after the forecast period, income stabilizes.

\subsection{Subjective sources of divergences}

Subjective sources of methodological errors may be found in the property surveys themselves. They may be manifested as short-term disturbances in the cognitive process or a relatively lasting bias towards such irregularities (STACHAK 2006, P 22-26). Short-term disturbances are the consequence of natural fluctuations in concentration, the build-up of emotions, as well as tiredness. Insufficient methodological qualifications and periodic haste, which reduces the accuracy of reasoning and the accuracy of observations, as well as the quality of work performed, often contribute to such errors. In practice, this means that the same valuer who reliably pursues his or her profession may draw up a property valuation report which significantly differs from the standard required and maintained by that valuer.

The relatively permanent tendency to make mistakes is believed by psychologists to be a type of restriction in the functioning of the human psyche, occurring in the brain subconsciously as cognitive barriers. Inherent tendencies and tendencies acquired in the social environment may be identified. Their consequences include an aversion to intellectual effort, stereotypical thinking, and accepting naive opinions. "The social environment is sometimes the source of cognitive errors to the extent to which it incorrectly educates and motivates, and thus reinforces the tendency to slapdash cognition," (STACHAK 2006 P. 24). Society is also the source of errors through omission, when no solid work habits are developed. This means that subjective sources of methodological errors occur not only in individually operating valuers, but that the responsibility for them falls on professional organizations. They do not supervise the process of teaching at universities at the stage of drawing up teaching programs which are to be implemented by those universities, they do not promote the teaching staff, nor do they participate in supervising the progress of professional training. The professional organizations in Poland turned out to be insufficiently active at the stage of organizing and creating training courses to improve professional qualifications; they does not enforce the requirement to improve qualifications through continuing education, and have failed to develop methodology textbooks which would be approved of in professional circles, and which show the best practice. The Federation's website should promote good universities, courses and textbooks, as well as good lecturers and those who are good at conducting professional training.

The weakness of the professional organization was manifested in the lack of agreements on professional standards by the legislator, which led to the suspension of those standards, diminishing of the prestige of the property valuer's profession and thus removing the criteria for assessing their practice in the eyes of their clients, making the valuers defenseless, left with only succinct, unclear provisions of the legislator, which enhanced their tendency to slapdash cognition. It is not the law that should regulate the complexities of the valuation methodology. They should be interpreted by professional standards, reinforced by methodology textbooks and high-quality literature on the subject, and promoted by the organization. The lack of these actions on the part of the organization contributes to increasing the uncertainty of an individual valuation, as well as the uncertainty between two valuations. The organization may influence the correction of the inherent tendency to make methodological errors through a training system, as well as through the work of the Arbitration Commission, but also - possibly first and foremost - the correction of tendencies acquired in the social environment through correct education and motivation, developing solid work habits.

\section{Summary}

Following a period of doubtful achievements in the building of the profession of a property valuer in 
Poland $^{3}$, the prestige of this profession in the eyes of recipients of property valuation reports as well as in the eyes of society has been diminishing rapidly. Unfortunately, the reasons behind such negative changes are, besides the fact that the practice is incompliant with the professional ethics code, methodological errors made in property valuation reports. The research conducted for the purpose of this publication reveals the scale of the problem.

Objective and subjective sources of methodological errors have been identified. The list of subjective sources is dominated by the weakness of the professional organization. The lack of radical, quick changes will result in the group of over five thousand property valuers, deprived of property valuation standards as well as the interpretation of valuation principles in methodology textbooks and books promoted by the professional organization, being left with merely concise and often misleading legal provisions. The property valuation methodology, understood as a set of valuation principles, has a number of subtleties which cannot be resolved by the legislator. The law constitutes a framework, while the valuation reflects the behavior of market participants. Such a situation going unchanged is dangerous not only to the profession of property valuers but also to the recipients of valuations, as it increases the uncertainty of an individual valuation and uncertainty between valuations.

\section{Reference}

Europejskie Standardy Wyceny (European Valuation Standards) 2012, seventh edition, Polish Federation of Valuers' Associations, Warszawa 2013

FISHER J. D., 2002, Real Time Valuation, Journal of Property Investment \& Finance, Vol. 20, No. 3

FRENCH. N., GABRIELLI N., 2003, The Uncertainty of Valuation, ERES, Helsinki

GILBERTSON B., 2001, Valuation or Appraisal: Art or Science? Global Real Estate Now, Spring 2001

KUCHARSKA-STASIAK E., 2013, Uncertainty of Property Valuation as a Subject of Academic Research, Real Estate Management and Valuation, Issue 4

MACKMIN D., 1999, Valuation of Real Estate In Global Markets, Property Management,Vol.17 No 4 ,

Międzynarodowe Standardy Wyceny (International Valuation Standards) 2011, Polish Federation of Valuers' Associations, Warszawa 2011

Rejestr Cen i Wartości prowadzony przez Urząd Miasta w Olsztynie (Register of Real Estate Prices and Values kept by the Olsztyn City Office)

Słownik języka polskiego (Polish language dictionary), edited by W. Doroszewski, PWN, 2000, electronic version

Słownik języka polskiego (Polish language dictionary), edited by M. Szymczak, PWN, Warszawa 1999,

STACHAK S., 2006, Podstawy metodologii nauk ekonomicznych (Fundamentals of methodology of economic sciences), Książka i Wiedza, Warszawa

Ustawa z dnia 24 marca 1920 r. o nabywaniu nieruchomości przez cudzoziemców, Dz. U. z 2004 r. nr 167, poz. 1758, z późn. zm. (Act of 24 March 1920 on the purchase of real estate by non-citizens, Journal of Laws, 2004, No. 167, item 1758, as amended).

The Appraisal of Real Estate, The Appraisal Institute of Canada

\section{Appendix No. 1}

\begin{tabular}{|c|c|c|c|c|c|}
\hline Item & $\begin{array}{l}\text { Location of } \\
\text { real estate, } \\
\text { function }\end{array}$ & $\begin{array}{l}\text { Market value } \\
\text { interpretation }\end{array}$ & $\begin{array}{l}\text { Evaluation of the } \\
\text { real estate market } \\
\text { analysis } \\
\text { conducted for the } \\
\text { purpose of } \\
\text { valuation }\end{array}$ & $\begin{array}{l}\text { Evaluation of selection and } \\
\text { procedure of the approach applied }\end{array}$ & $\begin{array}{l}\text { Result } \\
\text { analysis }\end{array}$ \\
\hline 1 & $\begin{array}{l}\text { Zamość, } \\
\text { commercial } \\
\text { function }\end{array}$ & $\begin{array}{l}\text { Current method } \\
\text { of use. No } \\
\text { extreme } \\
\text { transactions }\end{array}$ & $\begin{array}{l}\text { Not very similar } \\
\text { real property } \\
\text { adopted for } \\
\text { comparison }\end{array}$ & $\begin{array}{l}\text { The comparative approach - the } \\
\text { paired comparison method - was } \\
\text { used, despite the fact that the } \\
\text { market of commercial property was }\end{array}$ & none \\
\hline
\end{tabular}

${ }^{3}$ An expression of recognition for the development of real estate valuation methodology and the profession of a property valuer in Poland was the organization of the World Conference of Property Valuers in Warsaw in 1996. 
were rejected,

which means

that the value

does not reflect

typical, i.e. most

frequently

occurring, prices

poorly developed. The period of

analysis was extended to 36

months. The application of the

income-based approach would

have been more appropriate, as it

would have allowed value in so-

called "real time" to be determined,

i.e. as of the valuation date

Despite the fact that during the

survey period (2 years) a "deficit of

similar property sold on the

market" occurred (p. 8 of the

The analysis

Szczecin, commercial function

2 (educational and office building)
Search for the typical price for the current method of use covered two years and referred to the investment market; it showed that not very similar real property was traded property valuation report), the comparative approach - the paired comparison method - was used. Not very similar property was used for comparisons: with differences in development size (valued: $2,468 \mathrm{~m}^{2}$, taken for comparison: $706 \mathrm{~m}^{2}$ ), the area of land $\left(3,429 \mathrm{~m}^{2}\right.$ as compared to the two compared properties with an area of over $7,000 \mathrm{~m}^{2}$ ), and legal status (sale of shares). This feature was not taken into account in the valuation.

\begin{tabular}{|c|c|c|c|c|c|}
\hline 3 & $\begin{array}{l}\text { Rymanów, } \\
\text { commercial } \\
\text { function, } \\
\text { sanatorium } \\
\text { facilities }\end{array}$ & $\begin{array}{l}\text { Current method } \\
\text { of use, the } \\
\text { potential } \\
\text { existing in the } \\
\text { property was } \\
\text { not reflected, } \\
\text { buildings are } \\
\text { empty and in } \\
\text { this condition } \\
\text { have no market } \\
\text { value, there was } \\
\text { no search for } \\
\text { typical prices }\end{array}$ & $\begin{array}{l}\text { Because sanatoria } \\
\text { and guesthouses } \\
\text { are rarely sold in } \\
\text { the local market, a } \\
\text { four-year period } \\
\text { of analysis was } \\
\text { adopted }\end{array}$ & $\begin{array}{l}\text { Comparative approach, paired } \\
\text { comparison method. The buildings } \\
\text { require general refurbishment and } \\
\text { modernization, the lack of a similar } \\
\text { property which had recently } \\
\text { constituted the subject of } \\
\text { transactions justifies the use of the } \\
\text { income-based approach, the } \\
\text { discounted income technique }\end{array}$ & $\begin{array}{l}\text { No } \\
\text { result } \\
\text { analysis, } \\
\text { price } \\
\text { hypo- } \\
\text { thesis } \\
\text { for } 1 \mathrm{~m}^{2} \\
\text { is higher } \\
\text { than for } \\
\text { the } \\
\text { compar- } \\
\text { able } \\
\text { proper- } \\
\text { ty, no } \\
\text { justificat } \\
\text { ion }\end{array}$ \\
\hline 4 & $\begin{array}{l}\text { Lędzin, } \\
\text { Karnice } \\
\text { gmina, } \\
\text { property } \\
\text { developed } \\
\text { with a } \\
\text { windmill, } \\
\text { adapted as a } \\
\text { guesthouse }\end{array}$ & $\begin{array}{l}\text { The current } \\
\text { method of use } \\
\text { may be deemed } \\
\text { most } \\
\text { advantageous }\end{array}$ & $\begin{array}{l}\text { There was no } \\
\text { similar property } \\
\text { on the market }\end{array}$ & $\begin{array}{l}\text { Comparative approach, paired } \\
\text { comparison method. No similar } \\
\text { property on the market, and the } \\
\text { commercial nature of the property } \\
\text { suggests that the application of the } \\
\text { income-based approach was } \\
\text { justified }\end{array}$ & $\begin{array}{l}\text { No } \\
\text { result } \\
\text { analysis }\end{array}$ \\
\hline 5 & $\begin{array}{l}\text { Dąbrowa } \\
\text { Górnicza, } \\
\text { utility } \\
\text { function }\end{array}$ & $\begin{array}{l}\text { Current method } \\
\text { of use, there was } \\
\text { no search for } \\
\text { typical } \\
\text { transaction } \\
\text { prices, extreme } \\
\text { transactions } \\
\text { were not } \\
\text { rejected }\end{array}$ & $\begin{array}{l}\text { Because the } \\
\text { investment } \\
\text { market of utility } \\
\text { premises was } \\
\text { poorly developed, } \\
\text { the analysis was } \\
\text { extended to } \\
\text { include other } \\
\text { locations within } \\
\text { the voivodeship }\end{array}$ & $\begin{array}{l}\text { Comparative approach, average } \\
\text { price adjustment method. No } \\
\text { description of properties adopted } \\
\text { for comparisons, only a description } \\
\text { of extreme properties provided }\end{array}$ & $\begin{array}{l}\text { Poor } \\
\text { result } \\
\text { analysis }\end{array}$ \\
\hline
\end{tabular}

Szczecin comercial function (educati onal and office building) 


\begin{tabular}{|c|c|c|c|c|c|}
\hline 6 & $\begin{array}{l}\text { Zgorzelec, } \\
\text { hospital }\end{array}$ & $\begin{array}{l}\text { Current method } \\
\text { of use, there was } \\
\text { no search for } \\
\text { typical } \\
\text { transaction } \\
\text { prices, extreme } \\
\text { transactions } \\
\text { were not } \\
\text { rejected }\end{array}$ & $\begin{array}{l}\text { Market analysis } \\
\text { does not contain } \\
\text { any numerical } \\
\text { data, }\end{array}$ & $\begin{array}{l}\text { Income-based approach, investment } \\
\text { method, simple capitalization } \\
\text { technique. The discount rate not } \\
\text { distinguished from the } \\
\text { capitalization rate. Incorrectly } \\
\text { calculated discount rate }\end{array}$ & $\begin{array}{l}\text { No } \\
\text { result } \\
\text { analysis }\end{array}$ \\
\hline 7 & $\begin{array}{l}\text { Gniew, } \\
\text { office } \\
\text { building }\end{array}$ & $\begin{array}{l}\text { Current method } \\
\text { of use, there was } \\
\text { no search for } \\
\text { typical } \\
\text { transaction } \\
\text { prices, extreme } \\
\text { transactions } \\
\text { were not } \\
\text { rejected }\end{array}$ & $\begin{array}{l}\text { Because the } \\
\text { investment } \\
\text { market of office } \\
\text { premises was } \\
\text { poorly developed, } \\
\text { the analysis was } \\
\text { extended to } \\
\text { include other } \\
\text { locations within } \\
\text { the voivodeship }\end{array}$ & $\begin{array}{l}\text { Comparative approach, average } \\
\text { price adjustment method }\end{array}$ & $\begin{array}{l}\text { Result } \\
\text { analysis } \\
\text { avail- } \\
\text { able }\end{array}$ \\
\hline 8 & $\begin{array}{l}\text { Bogatynia, } \\
\text { commercial } \\
\text { function } \\
\text { building }\end{array}$ & $\begin{array}{l}\text { The most } \\
\text { advantageous } \\
\text { method of use is } \\
\text { a continuation } \\
\text { of the current } \\
\text { method, search } \\
\text { for the typical } \\
\text { price }\end{array}$ & $\begin{array}{l}\text { The lack of } \\
\text { transactions } \\
\text { resulted in the } \\
\text { research area } \\
\text { being extended }\end{array}$ & $\begin{array}{l}\text { Comparative approach, paired } \\
\text { comparison method. Incorrect } \\
\text { justification of the rejection of the } \\
\text { income-based approach: "there is } \\
\text { little probability that the entire } \\
\text { space will be rented out" }\end{array}$ & $\begin{array}{l}\text { No } \\
\text { result } \\
\text { analysis }\end{array}$ \\
\hline 9 & $\begin{array}{l}\text { Ubocze, } \\
\text { manufacturi } \\
\text { ng and } \\
\text { warehouse } \\
\text { function }\end{array}$ & $\begin{array}{l}\text { Current method } \\
\text { of use, there was } \\
\text { no search for } \\
\text { typical } \\
\text { transaction } \\
\text { prices, extreme } \\
\text { transactions } \\
\text { were not } \\
\text { rejected, the } \\
\text { value is } \\
\text { interpreted as } \\
\text { an average }\end{array}$ & $\begin{array}{l}\text { No market } \\
\text { analysis } \\
\text { appropriate for } \\
\text { the purpose of this } \\
\text { valuation. No } \\
\text { citation of } \\
\text { transactions } \\
\text { adopted for } \\
\text { comparisons, }\end{array}$ & $\begin{array}{l}\text { Comparative approach, average } \\
\text { price adjustment method. No } \\
\text { description of features of the } \\
\text { property compared. Low } \\
\text { probability that the property } \\
\text { adopted for comparisons is similar. } \\
\text { The calculation of the replacement } \\
\text { value of buildings is } \\
\text { incomprehensible }\end{array}$ & $\begin{array}{l}\text { No } \\
\text { result } \\
\text { analysis }\end{array}$ \\
\hline 10 & $\begin{array}{l}\text { Wrocław, } \\
\text { residential } \\
\text { and utility } \\
\text { function }\end{array}$ & $\begin{array}{l}\text { Current method } \\
\text { of use, which } \\
\text { may be deemed } \\
\text { the most } \\
\text { advantageous } \\
\text { one. Search for } \\
\text { the typical price } \\
\text { for the current } \\
\text { method of use }\end{array}$ & $\begin{array}{l}\text { There was no } \\
\text { similar property } \\
\text { on the market }\end{array}$ & $\begin{array}{l}\text { Comparative approach, average } \\
\text { price adjustment method. No } \\
\text { description of features of the } \\
\text { property compared. The method } \\
\text { applied is not adequate to the data } \\
\text { collected from the market: property } \\
\text { which is not similar in terms of the } \\
\text { area of the property was taken for } \\
\text { the valuation }\end{array}$ & $\begin{array}{l}\text { No } \\
\text { result } \\
\text { analysis }\end{array}$ \\
\hline 11 & $\begin{array}{l}\text { Zieleniewo, } \\
\text { economic } \\
\text { function }\end{array}$ & $\begin{array}{l}\text { Current method } \\
\text { of use, the } \\
\text { potential in the } \\
\text { property has not } \\
\text { been revealed. } \\
\text { Extreme } \\
\text { transactions } \\
\text { were not } \\
\text { rejected }\end{array}$ & $\begin{array}{l}\text { There was no } \\
\text { similar property } \\
\text { in terms of area on } \\
\text { the market }\end{array}$ & $\begin{array}{l}\text { Comparative approach, average } \\
\text { price adjustment method. Lack of } \\
\text { understanding of valuation } \\
\text { methodology: the market value } \\
\text { constitutes the total of the land } \\
\text { value and the replacement value of } \\
\text { the building, adjusted by the value } \\
\text { of the four-year tenancy agreement. }\end{array}$ & $\begin{array}{l}\text { No } \\
\text { result } \\
\text { analysis }\end{array}$ \\
\hline 12 & $\begin{array}{l}\text { Łapy, } \\
\text { industrial, } \\
\text { administrati } \\
\text { ve and } \\
\text { service }\end{array}$ & $\begin{array}{l}\text { Current method } \\
\text { of use, no } \\
\text { deliberations } \\
\text { about the most } \\
\text { advantageous }\end{array}$ & $\begin{array}{l}\text { There was no } \\
\text { similar property } \\
\text { in terms of area on } \\
\text { the market }\end{array}$ & $\begin{array}{l}\text { Income-based approach, simple } \\
\text { capitalization method. For the } \\
\text { purpose of isolating the value of } \\
\text { land, the comparative approach, } \\
\text { average price adjustment method, }\end{array}$ & $\begin{array}{l}\text { Result } \\
\text { analysis } \\
\text { avail- } \\
\text { able }\end{array}$ \\
\hline
\end{tabular}




\begin{tabular}{|c|c|c|c|c|c|}
\hline & function & $\begin{array}{l}\text { method, } \\
\text { although the } \\
\text { value of land is } \\
\text { similar to the } \\
\text { value of } \\
\text { buildings. The } \\
\text { technical } \\
\text { condition of the } \\
\text { buildings is } \\
\text { average. The } \\
\text { value of the } \\
\text { property is } \\
\text { interpreted as } \\
\text { an average. } \\
\text { Extreme } \\
\text { transactions } \\
\text { were not } \\
\text { rejected }\end{array}$ & & $\begin{array}{l}\text { was used. Lack of description of } \\
\text { features of the properties } \\
\text { compared. The method applied is } \\
\text { not adequate to the data collected } \\
\text { from the market: property which is } \\
\text { not similar in terms of the area of } \\
\text { the property was taken for the } \\
\text { valuation of the land. }\end{array}$ & \\
\hline 13 & $\begin{array}{l}\text { Głogów, } \\
\text { teaching } \\
\text { function }\end{array}$ & $\begin{array}{l}\text { Current method } \\
\text { of use, no } \\
\text { deliberations } \\
\text { about the most } \\
\text { advantageous } \\
\text { method. } \\
\text { Extreme } \\
\text { transactions } \\
\text { were not } \\
\text { rejected }\end{array}$ & $\begin{array}{l}\text { No rental market } \\
\text { analysis }\end{array}$ & $\begin{array}{l}\text { For part of the property - income- } \\
\text { based approach, simple } \\
\text { capitalization method (erroneously } \\
\text { referred to as the profit method), } \\
\text { for the remaining part - } \\
\text { comparative approach, paired } \\
\text { comparison method. No } \\
\text { understanding for the income- } \\
\text { based approach: capitalization rate } \\
\text { calculated from the capital market } \\
\text { without the adjustment for income } \\
\text { change. The discount rate is } \\
\text { equated with the reverse of the } \\
\text { capitalization rate. Data on rent } \\
\text { rates and operating expenses taken } \\
\text { from the property in question. }\end{array}$ & $\begin{array}{l}\text { No } \\
\text { result } \\
\text { analysis }\end{array}$ \\
\hline 14 & $\begin{array}{l}\text { Chorzów, } \\
\text { service } \\
\text { function } \\
\text { (hospital) }\end{array}$ & $\begin{array}{l}\text { Current method } \\
\text { of use, the most } \\
\text { advantageous } \\
\text { method of use } \\
\text { was considered }\end{array}$ & $\begin{array}{l}\text { Well conducted } \\
\text { market analysis }\end{array}$ & $\begin{array}{l}\text { Income-based approach, investment } \\
\text { method, simple capitalization } \\
\text { method. For the purpose of } \\
\text { isolating the value of land, the } \\
\text { average price adjustment method } \\
\text { was applied. No differentiation } \\
\text { between the discount rate and the } \\
\text { capitalization rate }\end{array}$ & $\begin{array}{l}\text { Result } \\
\text { analysis } \\
\text { avail- } \\
\text { able }\end{array}$ \\
\hline
\end{tabular}

